\title{
Lookıng Through the Lenses: Turkey-Eu Relations Is It a Game of Chess or a Chartless Journey?
}

\author{
Pa Modou Drammeh \\ Ege University, Turkey
}

\begin{abstract}
As an incontrovertible fact, the Turkey-EU relation is getting riveting by the day. The determinations of the bloc not to admit Turkey to the EU has diluted Turkish political reforms and programmes. The decision of the bloc to block Turkey from becoming a fully fledged member of the EU is it politically motivated or is Turkey responsible for her own political foul-up? This paper uses different colour lenses in an attempt to synthesize the chemistry between the two parties in question. This paper focuses on the critical issues unfolding before our eyes as far as the Turkey-EU relation is concerned. In the same vein, it examines many critical issues worthy of consideration. Turkey has subscribed to several agreements with the European Union and found herself on the list of candidates whose memberships have not yet been accepted. This paper investigates critically into the relation of Turkey with the European Union, its evolution through time, and up-to-the-minute situations. This paper further seeks to shed light on the possible reasons why Turkey is not admitted to the EU and its possible membership.
\end{abstract}

Keywords: European Union, Turkey, relations, agreement, accessions, membership, European Parliament, negotiations

DOI: $10.7176 / \mathrm{IAGS} / 71-03$

Publication date: April $30^{\text {th }} 2019$

\section{Introduction: What is the EU?}

Essentially, the European Union is a structure of democratic states, acting collectively through an institutionalized system of decision-making. When joining the European Union, members sign up not only the body of EU treaties, legislation, and norms ( the so-called acquis communautaire), but also a set of shared common values, based on democracy, human rights, and principles of social justice (Michelle Cini, 2003). At the point of writing this paper, the EU as a bloc has a membership of 28 countries and all these 28 countries have a membership status in the Council of Europe because no country has ever joined the European Union without first belonging to the Council of Europe. Turkey officially joined the Council of Europe as a fully fledged member but that does not add weight to her case. The Council of Europe should not be confused with the European Concil. The European Council is part of the structures of the EU while the Council of Europe is not. What is referred today as the EU started with the ECSC. Historically, the ECSC was institutionalized in Paris in 1951 (The Treaty of Paris). The ECSC had six founding members at the time: These founding members included the three Benelux countries of Belgium, France, Germany. In addition to these three Benelux countries, came Italy, Luxembourg and the Netherlands. The ECSC later became the EEC. This development took place in 1958 under what was referred to as the Treaty of Rome and later on the EEC became the EC. The early focal point of the EC was agricultural policy and the removal of custom barriers. In 1973 Denmark, Ireland and Britain were admitted to the EC. In Summary, the 1993 Maastrict Treaty gave birth to the name EU. The EU then replaced the EC.

\section{Why was the European Union founded?}

It was constituted as a consequence of the negative experience of the founding member states in the immediate aftermath of the Second World War. The basic idea was to find perpetual peace among member states. Maintaing peace was a primary goal for the EU. The EU also wanted to boost the economic status of member states after the WW2.

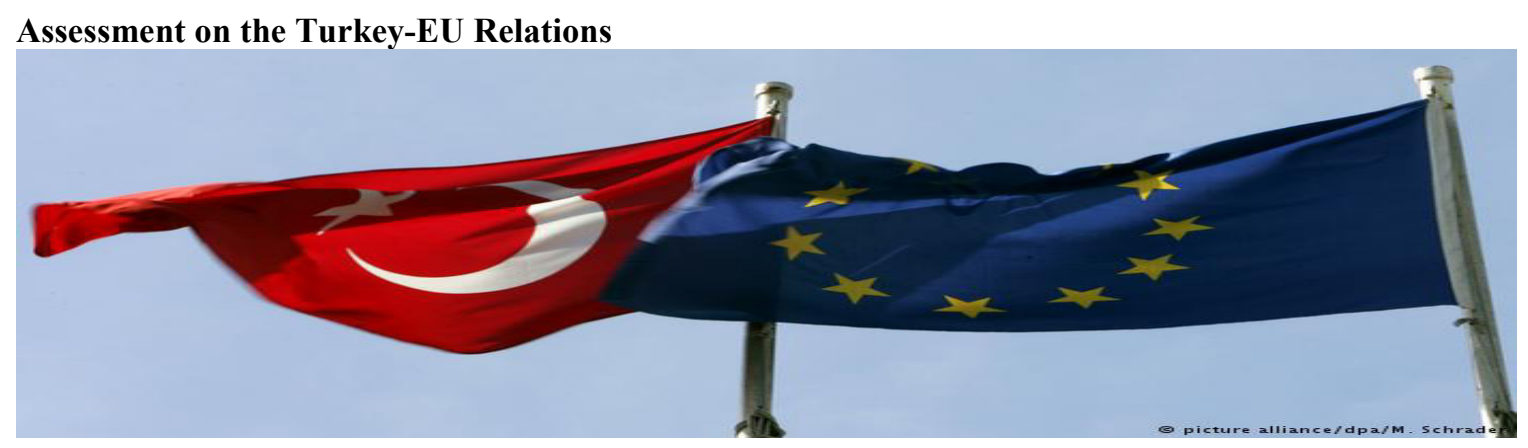




\section{Photo Credit: DW}

The paper furnishes a useful overview of the Turkey-EU relation after giving the reader a glimpse of the ebbs and flows in the relations. The cementation of a relation between Turkey and the EEC started concisely after the creation of the EEC in 1959. This relation was officially validated in 1963 upon the signing of the "Ankara Agreement.' The purpose of the agreement was found in its second article as; "The aim of this Agreement is to promote the continuous and balanced strengthening of trade and economic relations between the Parties, while taking full account of the need to ensure and accelerated development of the Turkish economy and to improve the level of employment and the living conditions of Turkish people"(TOA, 1963). Turkey shares land border with two EU member states: Bulgaria and Greece. Both countries are members of the EU. Interesting right? But Turkey is still not a member. In 1987, Turkey applied to join the bloc but her application was not endorsed. It would interest the reader to know that Turkey has a membership status in the Council of Europe. Turkey was also a member of the WEU. "Turkey endorsed a Customs Union agreement with the EU in 1995 and was formally recognized as a candidate for full membership on 12 December 1999, at the Helsinki summit of the European Council" (www.europarl.europa.eu). But since after the attempted coup in 2016, accession negotiations have stained. Officials of the EU had this to say: "planned Turkish policies violate the Copenhagen criteria of eligibility for a EU membership." Moreover, this was what the EU's General Affairs Council had to say on 26 June 2018: "the Council notes that Turkey has been moving further away from the European Union. Turkey's accession negotiations have therefore effectively come to a standstill and no further chapters can be considered for opening or closing and no further work towards the modernisation of the EU-Turkey Customs Union is foreseen." As far as the EU is concerned enlargement is a crucial policy tool. It is a mechanism that helps to widen peace, order, prosperity, human rights etc. across the European geographical area. In October 2005 accession negiations were opened with Turkey and Croatia. The negotiation was for the countries involved to adopt and implement the European Union body of law. This body of law was famed as acquis. It incorporates the rules that should be obeyed by EU member states. Turkey as a candidate, needs to adopt a respectable part of its national legislation in line with the EU law. This means cardinal changes for society that will touch on virtually all sectors of the country from the environment to the bench. In order to become a member state, it is of necessity for the candidate country to bring its structures, governance capability and legal mechanism up to EU modular, domestically and transitionally. This allows them to apply the acquis efficaciously upon assenting. In the same vein it facilitates smooth enforcement of the acquis before accession takes place. Turkey having failed to comply with the standards and principles of the EU, a decision to suspend negiotiation talks with Turkey was reached in November 2016. This decision was finalized by the European Parliament. However, the decision was not binding. The circumstances leading to this decision was EU's concerns over the poor human rights records of Turkey at the time.

\section{Positions of EU member states on Turkey}

Turkey has always be longing to become a fully fledged member of the EU, but members of the bloc have mixed feelings about the partnership. This paper examines the mixed feelings of EU member states on the EU-Turkey negotiation talks. The eligibility of Turkey to join the EU was recognized in 1997. However, negotiation talks did not start until 2005. Later on the Turkey-EU relation was getting more complicated like a spider web. Things were not happening as it was anticipated or expected to be. Presently, the Turkey-EU relation is not getting on well.

Some members of the EU are against Turkey's membership application to the EU. Germany, one of the countries that has the biggest negotiating power in the EU is totally against Turkey's membership application. As alleged, some German nationals were illegally arrested in Turkey. Following this unfortunate political developement, the Chancellor of Germany, Angela Merkel proposed to the EU to suspend having any negotiation talks with Turkey. This proposal of the German Chancellor was further motivated by the call made by the Turkish President Erdogan asking the Turks who lived in Germany at the time and were legally capable to exercise their civil rights not to vote for Chancellor Merkel in the election. Austria is also in the same boat with Germany. After the failed coup in 2016, the government of Austria also proposed to the EU what Chancellor Merkel proposed earlier. This call was stimulated by the way the Turkish government handled the matter in the aftermath of the attempted coup. Belgium used to support Turkey to be admitted to the EU but not anymore. In March, Prime Minister Charles Micheal shifted stance and followed suit. In his view Turkey government has departed from European values.

Some countries remain on the fence. France remains on the fence. President Nicolas was staunchly opposed to any form of partnership. But under Francois Hollande there is a stabilized relation as he has not declared his position formally. Luxembourg and Denmarks also remain neutral. Luxembourg neither supports nor rejects Turkey's membership application. Denmark's position is similar to that of Luxembourg. Historically, the UK government has been showing support to Turkey. However, the UKIP is reported to have said that if Turkey is admitted to the EU there would be more Muslim immigrants. 
Some member states of the EU also want Turkey to be admitted to the EU. Ireland supports Turkish accession but never hesitated to stress that Turkey must be committed to the EU beliefs and standards. The Mediterranean neighbour countries of Malta, Spain, Italy and Portugal also want to see the negotiation talks to progress. "While Portugal generally supports giving other countries a chance to benefit from EU membership as it did, Spain sees a close relationship between Brussels and Ankara as key for geopolitical stability in the region. Italy, meanwhile, is Turkey's third most important EU trade partner." see $D W$. The Nordic countries of Finland and Sweden have also been supportive to the negotiation talks between the two parties. Latvia, Lithuana and Estonia also support Turkey's membership application to the EU. As $D W$ puts it, "Turkey has been a strong security and defense partner to the three countries since their accession to NATO in 2004. Poland, the Czech Republic, Slovakia, Hungary, Romania and Bulgaria are also positive about Turkey joining the European Union. There is little debate in Poland and the Czech Republic about Turkish accession." Romania has openly declared her support for Turkey. With the backing of Turkey, Romania got admitted to NATO in 2004. Slovenia's attitude towards this issue is very carefree pe se. Croatia supports Turkey's membership application to the EU. Greece and Cyprus supports Turkish accession. They believe that Turkey joining the bloc could lead to a more peaceful relations.

\section{Why has Turkey not been admitted to the European Union?}

This is a question asked by many and still it is a concern for researchers. Many people have been inquisitive about what could be the equiprobable account for Turkey not being admitted to the European Union. This is an interesting development. "Turkey-EU accession has been hit by two exogenous shocks which have changed the context in which it operates: the migration issue since mid-2015 and the attempted coup d'etat on 15 July 2016 " (Gulay Icoz \& Natalie Martin 2016). Let me drive quickly into the arguments of Taylor and Francis. They argued: "The extreme political imperative on the EU's elite actors to make the deals of November 2015 and March 2016, to stem the flow of people across the Aegean Sea from Turkey to Greece, appears to have obliged the EU to look selectively at Turkey's record of liberal democracy" ( Taylor \& Francis 2005). Just as Phinnemore, D., and E. Icener put it, 'this special issue, not only had progress been 'glacial' since 2005 the discourse surrounding it was dominated by words such as 'impasse' and 'stalemate" (Phinnemore, D., and E. Icener. 2016. "Holding the Door Hal? Open: The EU and Turkey Ten Years on." Journal of Contemporary European Studies. (Special Issue). Surveying through the existing academic literature, this paper reason out some likely factors leading to the unsuccessful negotiation talks. Despite Turkey's membership status in many European affiliated organisations such as OECD and OSCE Turkey is yet to be admitted to the EU. As stated earlier, some EU member states such as Germany are against Turkey's membership application at the moment. It is merely my opinion that Germany would not like to admit another 73 million nation state to the EU, thence gravely weakening its hegemony in the European Parliament. Another fundamental element this paper argues as a factor is Turkey's traditional Cypriot and Kurdish problems. The ways in which the Turkish government have dealt with them have repeatedly affected Turkey's accession negotiations. This has always been a security concern to the EU. Turkey has been facing a terror problem with the Kurdish terror organization PKK for too long. The issue of migration is also a big concern to the EU member states in general and to the EU in particular. The refugee crisis of 2015 is still green. This refugee crisis was a big headache to the Europeans. Now what would be the result of admitting a Muslim country of such a poupulation to the European Union? This implies free movement of Turks between EU countries. Many Turks would pour into western Europe and other migrants would use Turkey as a gate way. Gulay Icoz \& Natalie Martin stated, "the July 2016 coup d'etat attempt has further stretched the credibility of any semblance of commitment to liberal democracy in Turkey with the wide scale 'purging' of tens of thousands of alleged conspirators not only in the military but in education, the judiciary and the media." In September 2016, over 10,000 sacked in new Turkey post-coup purge. According to Icoz, it is difficult for the Turkish authorities to meet the democratic credentials of the EU, and hindered the implementation of the necessary EU reforms. Some papers contend that Turkey has been moving away from the EU for a few years now. Turkey human rights record is sinking, Turkish secularism is dead or dying, Turkish democracy on the path to autocracy. Among the reasons is that many Europeans do not view Turkey as a European country and thus unfit to be admitted to the EU. It could also be argued that Turkey is not part of Europe in totally as far as geography is concerned. People still debate the borders of Europe and where it should end, with the current borders it's true that not all parts of Turkey are in Europe, but this isn't and shouldn't be a factor as there are other Eurosian countries that negotiate with EU for full membership. (e.g. Armenia, Azerbaijan.) And Turkey has already been a member of number of European organizations since its foundation. Turkey is also a majority-Muslim country and you know what that could mean to the EU. Turkey's economy at the time was a point of consideration. The economy was neither stable nor too good at the time.

\section{Turkey's acceptance to the $\mathrm{E} U$ will be a mutual benefit: $A=B$ and $B=A$ relations}

Jean Monnet and his likes who were the main pillars of European Integration were committed to defining 
common interest and sharing goals in order to defeat any culture that could bring emotion of intense dislike and doubts. Neither religious belief or secular values nor geographical boundary was a guiding principle for the integration process. In simple terminology, culture and religion were not taken into account for admitting a candidate to the EU. Unfortunately, the EU is now operating on that landscape if Turkey's case is taken into consideration. If partisan politics is wiped out of the system, the result would reveal that there is mutual interest and benefit in Turkey- EU membership but the game of politics is always playing its role. The European Union's motto is "united in diversity." If this was true to the latter then Turkey's case would have been different. The fundamental question one should ask is this: why is Turkey's membership application still hanging in the air when article 2 and 49 of the European Treaty defined in clear terms the membership criteria of the bloc. Articles 2 states: "The Union is founded on the values of respect for human dignity, freedom, democracy, equality, the rule of law and respect for human rights, including the rights of persons belonging to minorities. These values are common to the Member States in a society in which pluralism, non-discrimination, tolerance, justice, solidarity and equality between women and men prevail." And article 49 further states: "Any European State which respects the values referred to in Article 2 and is committed to promoting them may apply to become a member of the Union. The European Parliament and national Parliaments shall be notified of this application. The applicant State shall address its application to the Council, which shall act unanimously after consulting the Commission and after receiving the assent of the European Parliament, which shall act by an absolute majority of its component members. The conditions of admission and the adjustments to the Treaties on which the Union is founded, which such admission entails, shall be the subject of an agreement between the Member States and the applicant State. This agreement shall be submitted for ratification by all the contracting States in accordance with their respective constitutional requirements. The conditions of eligibility agreed upon by the European Council shall be taken into account." Based on the above citations, Turkey's membership application should be examined within above context. Turkey EU membership will be a win-win situation because there will be a common benefit especially in the domain of economic. From an economical viewpoint, the benefits of such accession are momentous. "The economic crisis, which is changing the economic climate and the architecture of the world economy, also shows that Turkey's accession offers considerable economic opportunities for the EU. Turkey is the 16th largest economy in the world and the 6th largest in Europe ( Statistics from the World Bank) and Turkey is expected to be the fastest growing economy of the OECD and Europe in the upcoming years ( OECD). Turkey is as part of the countries anticipated to render the essential input for economic recovery in the world. Turkey is the EU's 7th biggest trading partner and the EU is Turkey's main trading partner." (Bagls, E., \& Michel, L. 2011). It could be argued from these points that there is a manifested mutual benefits between the two parties. There is also an existing Custom Union that resolves around Turkey and the EU. Turkey has a large and flourishing domestic market and a good private sector making her to stand out in the region. Futhermore, Egemen Bagis and Louis Michel argued that "70 percent of the world's energy resources are located to the south and east of Turkey, while the world's largest energy consumer, Europe, is located to the west of Turkey. Turkey's central geographical position is also critical for the security and sustainability of energy supply to the EU."

\section{The Ambivalent Future: Turkey-EU Relations}

In recent time Turkey-EU relation is strained and the future is ambivalent. Turkey application to the EU has been hanging 'out there' for too long now. Turkey-EU relation explores the push and pull dynamics thence TurkeyEU relations have an exceedingly long history and still now Turkey could not obtain full membership to the EU. Will a time come when both parties will wholly brush aside the accession negotiations and turn their backs on each other? This will unlikely happen. They both have joint interest in economic isssues and trade. Apart from that the two parties share common interests in the Middle East. A more integrated relation is unlikely to happen but the two parties will likely cooperate for the greater good. The EU has a primal interest in cooperating with Turkey because Turkey's position in the Middle East is of crucial importance. For instance, managing the humanitarian situation in Syria. Moreover, Turkey is plays a very key role in controlling migration and has a top priority in fighting the act of terrorism. Today Turkey serves as an essential actor in minimizing the inflow of regugees into Europe as well as illegal migration. With the March 2016 agreement between Turkey and the EU, illegal migration has drastically reduced. The European Union also needs Turkey to secure peace and stability in the Middle East. Turkey is NATO's second biggest military power in terms of personnel. Geographically, Turkey is located in a very strategic position thereby making it easy for her to sustain peace in the Middle East. As a rising economic power Turkey has a big economic potential for the EU. Turkey also plays a pivotal role in the economic development and stableness of the Western Balkans, as well as the Black Sea and Caucasus regions. In the future, there will be a stronger cooperation between the two parties. However, the likelihood of Turkey having a full membership status in the EU is very limited. The future of Turkey-EU relations is groping. However there are likely possible destinations which EU-Turkey relations could arrive both in cooperation and conflict. This paper assumes that the EU will continue double-dealing with Turkish accession negotiations and a time will come even Turkey and her supporters in the EU will lose hope in any form of negiotiation talks and 
Turkey would likely abondon the negotiations. This is because Turkey will see the negotiation as a political failure and impossible to achieve. Another expectation could be that Turkey-EU relation would be restructured and a new honest start will emerge. This could be a new structure for cooperation. In this case both parties would brush off the accession negotiations and remain good couple in the development process. Turkey would likely establish partnership with the EU on many important issues to boost her economy and related areas. The most unlikley case would be Turkey becoming a fully fledged member of the EU. This could only be actualized if the EU reconcentrates more on the enlergement process and Turkey filling the gaps she ought to fill. Turkey would also work on her democracies deficits to facilitate this process because it might be easily argued that since the attempted coup of last year, and the crackdown that has followed it, Turkey no longer fulfils the Copenhagen political criteria. However, this paper argues that the snail-space-process in which the accession process has taken over the years is due to European Union not simply complying with article 2 and particularly article 49 of the treaty. This paper further argues that the EU'S attitude towards Turkey's membership application is partisan. Turkey's case is so different from the rest and has lasted for too long. This papers concludes by saying the future is uncertain.

\section{Endnotes}

Cini, M. (2003) European Union Politics.

Tocci (2004) Turkey and the European Union a journey to the unknown. Center on the United States and Europe at BROOKINGS

Bagis, E., \& Michel, L. (2011) Turkey and EU membership: a win win situation. euobserver.

Icoz, G., \& Martin N. (2016) Opportunities missed: Turkey-EU accession since 2005. Journal of Contemporary European Studies.

Phinnemore, D., \& E. Icener. 2016. "Holding the Door Hal? Open: The EU and Turkey Ten Years on." Journal of Contemporary European Studies. (Special Issue).

Dandul, H. O. (2013) Possible membership of Turkey to European Union and its Economic Aspects

European Commission: Accession negotiations with Turkey" . Retrieved 5 September 2017

"Fifty Years On, Turkey Still Pines to Become European". TIME. 8 September 2009. Retrieved 8 September 2009.

"Turkey is no longer an EU candidate", MEP says, Euronews

"Turkey's EU dream is over, for now, top EU official says". Hürriyet Daily News. 2 May 2017.

"Freeze EU accession talks with Turkey until it halts repression, urge MEPs". European Parliament.

"EU parliament votes overwhelmingly in favour of scrapping Turkey accession talks". The Telegraph. Retrieved 2016-12-08.

Taylor \& Francis, Turkey-EU accession since 2005.

See: https://freedomhouse.org/country/turkey.

www.quora.com

http://www.lisbon-treaty.org

World Bank statistics

Euobserver.com

www.worldatlas.com

www.europarl.europa.eu 